\title{
The Effect of Curcumin on the Acute Wound Healing of Mice
}

\author{
Armansjah Dara Sjahruddin ${ }^{1}$, Anis IrawanAnwar ${ }^{1}$, Farida Tabri ${ }^{1}$, Khairuddin Djawad ${ }^{1}$, \\ Dasril Daud ${ }^{2}$, Gemini Alam ${ }^{3}$
}

${ }^{1}$ Dermatovenereology Department, Medical Faculty Hasanuddin University, Makassar, South Sulawesi, Indonesia

${ }^{2}$ Pediatric Department, Medical Faculty Hasanuddin University, Makassar, South Sulawesi, Indonesia

${ }^{3}$ Pharmacy Faculty, Hasanuddin University, Makassar, South Sulawesi, Indonesia

\section{Email address:}

ariedara@yahoo.com (A. D. Sjahruddin), anisianwar@yahoo.co.id (A. I. Anwar), farida_tabri@yahoo.com (F. Tabri), duddindj@gmail.com (K. Djawad), ikkkfkuh@yahoo.co.id (G. Alam),drdasril@gmail.com (D. Daud)

\section{To cite this article:}

Armansjah Dara Sjahruddin, Anis IrawanAnwar, Farida Tabri, Khairuddin Djawad, Dasril Daud, Gemini Alam. The Effect of Curcumin on the Acute Wound Healing of Mice. American Journal of Clinical and Experimental Medicine. Vol. 3, No. 4, 2015, pp. 189-193.

doi: $10.11648 /$ j.ajcem.20150304.20

\begin{abstract}
Background: The study aimed to compare the effectiveness of curcumin $0.5 \%$ and $5 \%$ by $\mathrm{Natrium} \mathrm{Chloride}(\mathrm{NaCl})$ $0.9 \%$ in the acute wound healing of mice. Methods: This study was conducted at the Animal Laboratory and at the Department of Anatomical Pathology, Medical Faculty Hasanuddin University in Makassar, by using an experimental study. The samples consisted of 30 mice observed by the change of clinical and histopathological manifestations. Result: The study reveal that there was no significant difference between the application of curcumin 5\% and Natrium Chloride $0.9 \%$ in the healing wound. After seven days the length of significant reepithelization was $\mathrm{p}=0.026$ between curcumin $0.5 \%$ and Natrium Chloride $0.9 \%$. After the seventh day of treatment the density of polymorpho nuclear $(P M N)$ and macrophages was not significant $(p<0.05)$ in all three groups. Statistically, the thickness of fibroblast was significant, between Natrium Chloride $0.9 \%$ and curcumin $0.5 \%$ ( $p=0.049$ ), curcumin $5 \%(\mathrm{p}=0.006)$ after the treatment on day seven. Conclusions: The use of application topical curcumin is not better than the $\mathrm{NaCl} 0.9 \%$ in acute wound healing in mice.
\end{abstract}

Keywords: Clinical Manifestation, Curcumin, Histopathology, Natrium Chloride, Wound Healing

\section{Introduction}

Skin is the most extensive organ and has many diverse functions include protection, thermoregulation, sensation, wound healing and regeneration, as well as the physical appearance of a person. ${ }^{(1)}$ If there is an injury to the skin, it will disturb the anatomical structures and functions as a result of pathological processes. ${ }^{(2)}$

Definition of injury is a damage to the skin continuity, tissues in the body both internal and external, causing traumatic effects. ${ }^{(3)}$ Acute and chronic wounds have similarities and differences in physiological terms. Acute wounds healing after passing through four phases of wound healing, namely hemostasis, inflammation, proliferation, and remodeling. In contrast, chronic wounds have the same initial phase but has a longer duration of the phases of inflammation, proliferation, and remodeling that can lead to the occurrence of tissue fibrosis, leaving cicatrix or unhealed ulcer. ${ }^{(4)}$

Turmeric or Curcuma longa Linn (synonym of Curcuma domestica $\mathrm{Val}$ ) from Zingiberaceae family is one of the important types of medicinal plants and their use quite a lot in Indonesia. ${ }^{(5)}$ On traditional medicine, turmeric is used as an anti-inflammatory, which curcumin is concluded as balancer between pro and anti-inflammatory mediators, as well as antiseptic, anti-irittant, and anorexia. Curcuminoid, the active ingredient in turmeric that has a broad spectrum of biological activities. Besides, turmeric has significant antibacterial activity on Bacillus cereus, Staphyllococcus aureus and Pseudomonas aeruginosa. Provision of turmeric is also recognized as the appropriate therapy in wound healing. ${ }^{(6)}$

Wound healing process that aims to speed healing, is important to avoid infection in the wound, the longer duration of the phases of inflammation, proliferation, and remodeling resulting in tissue fibrosis and ulcers. Based on the statements above, it raised the interest to find out if curcumin has efficacy when administered topically to acute wound healing process in the hope of speeding up the duration of the third stage of wound healing when compared with the use of Natrium Chloride ( $\mathrm{NaCl}) 0.9 \%$ as wet dressings. 


\section{Materials and Methods}

This study is an animal experimental design to compare the effectiveness of topical curcumin $0.5 \%$ and $5 \%$ with $\mathrm{NaCl} 0.9 \%$ as wet dressing in mice within 3 and 7 days with a once daily application $(0,2 \mathrm{ml}$ topical). The curcumin concentration of $0.5 \%$ and $5 \%$ obtained by mixing it with ethanol $96 \%$ so that the form of a solution. The study was conducted in February -
March 2015 in Animal Laboratory and Department of Anatomical Pathology, Medical Faculty, Hasanuddin University Makassar. After receiving approval from the animal ethics committee, we obtained total sample is 30 albino strain of white mice of either sex, healthy, aged 10-12 weeks, and weight 20-30 grams. The sample was randomly selected a total of 30 samples to comply with the number of samples.

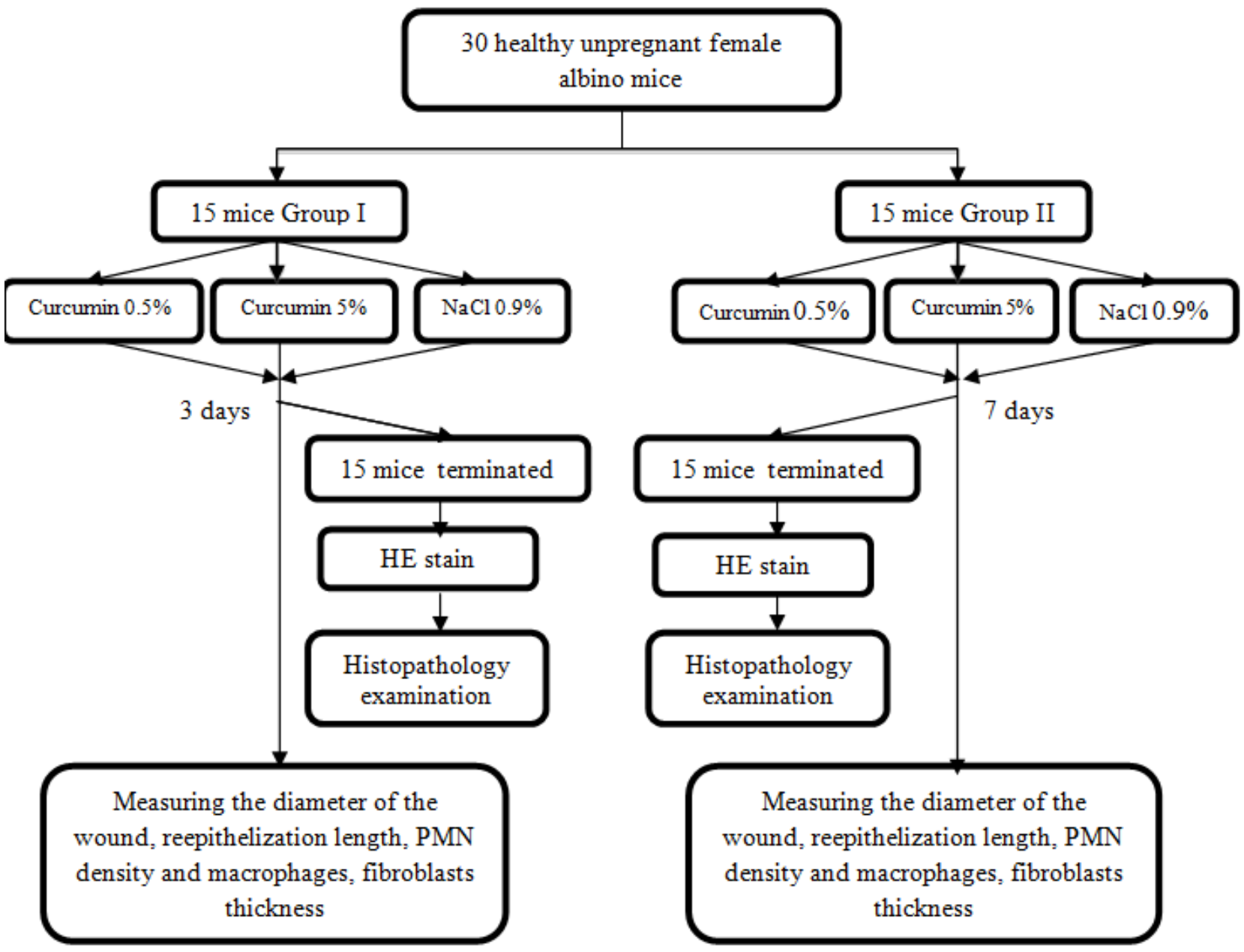

Figure 1. Study flow scheme.

We split into two groups observation on days 3 and 7 , is based on that process reepithelization started on day 3 , and epithelization in wet, moist, and dry wounds was completed by days $7 .^{(6)}$

Collected data were edited, tabulated and incorporated into a computer program, and then conducted a descriptive and analytical analysis. Results of the analysis will be presented in tables or graphs accompanied by explanations. Data analysis was performed using SPSS version 21. Statistical test was performed using ANOVA followed by t-test, independent test, with significance level $\mathrm{p}<0.05$.

\section{Results}

The data we obtained in this study are shown in the table below:
Table 1. The diameter of the wound after treatment day 3.

\begin{tabular}{lllllll}
\hline $\begin{array}{l}\text { Wound } \\
\text { Diameter }\end{array}$ & \multicolumn{2}{l}{ Curcumin 0.5\% } & \multicolumn{2}{l}{ Curcumin 5\% } & \multicolumn{2}{l}{ NaCl 0.9\% } \\
\hline (mm) & $\begin{array}{l}\text { SBefor } \\
\text { e }\end{array}$ & After & Before & After & Before & After \\
& $(\mathrm{n}=5)$ & $(\mathrm{n}=5)$ & $(\mathrm{n}=5)$ & $(\mathrm{n}=5)$ & $(\mathrm{n}=5)$ & $(\mathrm{n}=5)$ \\
Mean & 5 & 4.20 & 5 & 3.8 & 5 & 3.6 \\
Median & 5 & 4 & 5 & 4 & 5 & 4 \\
Sd & 0 & 0.45 & 0 & 0.45 & 0 & 0.55 \\
Min-Max & $5-5$ & $4-5$ & $5-5$ & $3-4$ & $5-5$ & $3-4$ \\
$\mathrm{p}$ & 0.016 & & 0.04 & & 0.005 & \\
\hline
\end{tabular}

$\mathrm{T}_{4}=4.00, \mathrm{p}=0.016(\mathrm{p}<0.05), \mathrm{T}_{4}=6.00, \mathrm{p}=0.04(\mathrm{p}<0.05), \mathrm{T}_{4}=5.72$, $\mathrm{p}=0.005(\mathrm{p}<0.01)$

Note : $\mathrm{T}_{4}=\mathrm{T}$ test paired sample $; \mathrm{Sd}=$ Standard deviation 
There was a significant difference in the administration of curcumin $0.5 \%$, curcumin $5 \%$ and $\mathrm{NaCl} 0.9 \%$ on the diameter of the wound before and after 3 days, which is characterized by reduced size of the diameter of the wound

Table 2. Comparison of the difference in diameter of the wound after treatment day 3

\begin{tabular}{llll}
\hline $\begin{array}{l}\text { Difference in } \\
\text { diameter wound }\end{array}$ & Curcumin $\mathbf{0 . 5 \%}$ & Curcumin 5\% & NaCl 0.9\% \\
\hline$(\mathrm{mm})$ & $(\mathrm{n}=5)$ & $(\mathrm{n}=5)$ & $(\mathrm{n}=5)$ \\
Mean & 0.8 & 1.2 & 1.4 \\
Median & 1.0 & 1.0 & 1.0 \\
Sd & 0.44 & 0.44 & 0.54 \\
Min-Max & $0-1$ & $1-2$ & $1-2$ \\
\hline
\end{tabular}

$\mathrm{F}_{2}=2.00, \mathrm{p}=0.178(\mathrm{p}>0.05)$

Note $: \mathrm{F}_{2}=$ ANNOVA test; $\mathrm{Sd}=$ Standard deviation

Table 2 above shows a comparison of the difference between the diameter of the wound at day 3 of treatment by administration of curcumin $0.5 \%$, curcumin $5 \%$ and $\mathrm{NaCl}$ $0.9 \%$, showed no significant difference.

Table 3. The diameter of the wound after treatment day 7.

\begin{tabular}{|c|c|c|c|c|c|c|}
\hline \multirow{2}{*}{$\begin{array}{l}\text { Wound } \\
\text { Diameter } \\
(\mathrm{mm})\end{array}$} & \multicolumn{2}{|c|}{ Curcumin $0.5 \%$} & \multicolumn{2}{|c|}{ Curcumin 5\% } & \multicolumn{2}{|c|}{ NaCl $0.9 \%$} \\
\hline & $\begin{array}{l}\text { Before } \\
(n=5)\end{array}$ & $\begin{array}{l}\text { After } \\
(n=5)\end{array}$ & $\begin{array}{l}\text { Before } \\
(n=5)\end{array}$ & $\begin{array}{l}\text { After } \\
(n=5)\end{array}$ & $\begin{array}{l}\text { Before } \\
(n=5)\end{array}$ & $\begin{array}{l}\text { After } \\
(\mathrm{n}=5)\end{array}$ \\
\hline Mean & 5 & 5.40 & 5 & 2.8 & 5 & 2.5 \\
\hline Median & 5 & 5 & 5 & 3 & 5 & 2.5 \\
\hline $\mathrm{Sd}$ & 0 & 1.14 & 0 & 0.84 & 0 & 0.50 \\
\hline Min-Max & $5-5$ & $4-7$ & $5-5$ & $2-4$ & $5-5$ & $2-3$ \\
\hline $\mathrm{p}$ & 0.477 & & 0.004 & & 0.000 & \\
\hline
\end{tabular}

$\mathrm{T}_{4}=0.784, \mathrm{p}=0.477(\mathrm{p}>0.05) \mathrm{T}_{4}=5.89, \mathrm{p}=0.004(\mathrm{p}<0.05) \mathrm{T}_{4}=11.18$ $\mathrm{p}=0.000(\mathrm{p}<0.05)$

Note $: \mathrm{T}_{4}=\mathrm{T}$ test paired sample $; \mathrm{Sd}=$ Standard deviation

Administration of curcumin $0.5 \%$ showed no significant difference before and after treatment, but the administration of curcumin $5 \%$ and $\mathrm{NaCl} 0.9 \%$ on the diameter of the wound for 7 days reveal any significant differences before and after treatment. It is characterized by the reduced size of the diameter of the wound at each awarding curcumin $5 \%$ and $\mathrm{NaCl} 0.9 \%$.

Table 4. Comparison of the difference in diameter of the wound after treatment day 7 .

\begin{tabular}{lll}
\hline Difference in wound diameter & Curcumin 5\% & NaCl 0.9\% \\
\hline$(\mathrm{mm})$ & $(\mathrm{n}=5)$ & $(\mathrm{n}=5)$ \\
Mean & 2.8 & 2.5 \\
Median & 2.0 & 2.5 \\
Sd & 0.84 & 0.5 \\
Min-Max & $1-3$ & $2-3$ \\
\hline
\end{tabular}

$\mathrm{T}_{8}=1.210, \mathrm{p}=0.303(\mathrm{p}>0.05)$

Note : $\mathrm{T}_{8}=$ Independent Test; $\mathrm{Sd}=$ Standard deviation

From the comparison of the difference in diameter of the wound on day 7 of treatment with curcumin administration and $\mathrm{NaCl} 0.9 \%$ to $5 \%$, showed no significant differences.

Table 5. Reepithelization after treatment day 3.

\begin{tabular}{llll}
\hline $\begin{array}{l}\text { Microscopic } \\
\text { wound length }\end{array}$ & Curcumin 0,5 & Curcumin 5\% & NaCl 0.9\% \\
\hline$(\mu \mathrm{m})$ & $(\mathrm{n}=2)$ & $(\mathrm{n}=2)$ & $(\mathrm{n}=2)$ \\
Mean & 191.5 & 191 & 236 \\
Median & 191.5 & 191 & 236 \\
Sd & 54.45 & 18.39 & 8.49 \\
Min-Max & $152-230$ & $178-204$ & $230-242$ \\
\hline
\end{tabular}

$\mathrm{F}_{2}=1.187, \mathrm{p}=0.417(\mathrm{p}>0.05)$

Note $: F_{2}=$ ANNOVA test; $\mathrm{Sd}=$ Standard deviation

Table 5 above showed no significant differences the reepithelization wound healing after treatment days 3 with curcumin $0.5 \%$, curcumin $5 \%$, and $\mathrm{NaCl} 0.9 \%$.

Table 6. Reepithelization length after treatment day 7.

\begin{tabular}{llll}
\hline $\begin{array}{l}\text { Reepithelization } \\
\text { length }\end{array}$ & $\begin{array}{l}\text { Curcumin } \\
\mathbf{0 . 5 \%}\end{array}$ & Curcumin 5\% & NaCl 0.9\% \\
\hline$(\mu \mathrm{m})$ & $(\mathrm{n}=4)$ & $(\mathrm{n}=4)$ & $(\mathrm{n}=5)$ \\
Mean & $178.5^{*}$ & 102 & $69^{*}$ \\
Median & 172 & 95.5 & 64 \\
Sd & 37.82 & 69.63 & 40.98 \\
Min-Max & $140-230$ & $26-191$ & $26-128$ \\
\hline
\end{tabular}

$\mathrm{F}_{2}=5.35, \mathrm{p}=0.026(<0.05)$

Note : $\mathrm{F}_{2}=$ ANNOVA test; $\mathrm{Sd}=$ Standard deviation

Post Hoc Bonferroni * $\mathrm{p}=0.026(\mathrm{p}<0.05)$

Table 6 above showed the reepithelization wound healing after 7 days of treatment found significant differences. In this case that showed the significant difference in the group that received $\mathrm{NaCl} 0.9 \%$ is the shortest length of the wound compared with two other treatments.

Tabel 7. PMN and macrophages density in wound healing after treatment day 3.

\begin{tabular}{llll}
\hline $\begin{array}{l}\text { PMN and } \\
\text { macrophages density }\end{array}$ & $\begin{array}{l}\text { Curcumin } \\
\mathbf{0 . 5 \%}\end{array}$ & Curcumin 5\% & $\begin{array}{l}\text { NaCl } \\
\mathbf{0 . 9 \%}\end{array}$ \\
\hline$(\%)$ & $(\mathrm{n}=4)$ & $(\mathrm{n}=4)$ & $(\mathrm{n}=5)$ \\
Mean & $62.6^{*}$ & $63.2^{*}$ & $35.8^{*}$ \\
Median & 60 & 63 & 30 \\
Sd & 8.57 & 9.42 & 19.99 \\
Min-Max & $53-73$ & $54-75$ & $13-60$ \\
\hline
\end{tabular}

$\mathrm{F}_{2}=6,540, \mathrm{p}=0,012(\mathrm{p}<0.05)$

Post Hoc Bonferroni * $\mathrm{p}=0,028(\mathrm{p}<0.05), \mathrm{p}=0,023(\mathrm{p}<0.05)$

Note : $F_{2}=$ ANNOVA test; $\mathrm{Sd}=$ Standard deviation

Table 7 above is visible density of PMN and macrophages wound healing after day 3 of treatment there appears to be significant differences among the 3 treatment groups. In this case the density of the smallest PMN and macrophages found in the group of $\mathrm{NaCl} 0.9 \%$ compared with the two other groups. 
Tabel 8. PMN and macrophages density in wound healing after treatment day 7.

\begin{tabular}{llll}
\hline $\begin{array}{l}\text { PMN and } \\
\text { macrophages density }\end{array}$ & $\begin{array}{l}\text { Curcumin } \\
\mathbf{0 . 5 \%}\end{array}$ & Curcumin 5\% & NaCl 0.9\% \\
\hline$(\%)$ & $(\mathrm{n}=5)$ & $(\mathrm{n}=5)$ & $(\mathrm{n}=5)$ \\
Mean & 52.6 & 32.4 & 62.8 \\
Median & 43 & 27 & 70 \\
Sd & 21.65 & 19.57 & 18.46 \\
Min-Max & $33-87$ & $8-57$ & $43-80$ \\
\hline
\end{tabular}

$\mathrm{F}_{2}=3,013, \mathrm{p}=0,087(\mathrm{p}>0.05)$

Note : $\mathrm{F}_{2}=$ ANNOVA test; $\mathrm{Sd}=$ Standard deviation

Table 8 showed no significant differences among the three groups that the density of PMN and macrophages of wound healing after 7 days.

Tabel 9. The thickness of fibroblasts in wound healing after treatment day 3.

\begin{tabular}{llll}
\hline $\begin{array}{l}\text { Fibroblast } \\
\text { length }\end{array}$ & Curcumin $\mathbf{0 . 5 \%}$ & Curcumin 5\% & NaCl 0.9\% \\
\hline$(\mu \mathrm{m})$ & $(\mathrm{n}=2)$ & $(\mathrm{n}=2)$ & $(\mathrm{n}=2)$ \\
Mean & 34 & 28 & 19 \\
Median & 34 & 28 & 19 \\
Sd & 4.25 & 4.25 & 0 \\
Min-Max & $31-37$ & $25-31$ & $19-19$ \\
\hline
\end{tabular}

$\mathrm{F}_{2}=9,500, \mathrm{p}=0.05(\mathrm{p}>0.05)$

Note $: \mathrm{F}_{2}=$ ANNOVA test; $\mathrm{Sd}=$ Standard deviation

From the table above it can be seen that the thickness of fibroblasts in wound healing after treatment days 3, there are no significant differences among the three groups.

Tabel 10. The thickness of fibroblasts in wound healing after treatment day 7.

\begin{tabular}{llll}
\hline $\begin{array}{l}\text { Fibroblast } \\
\text { length }\end{array}$ & Curcumin $\mathbf{0 . 5 \%}$ & Curcumin 5\% & NaCl 0.9\% \\
\hline$(\mu \mathrm{m})$ & $(\mathrm{n}=4)$ & $(\mathrm{n}=4)$ & $(\mathrm{n}=5)$ \\
Mean & $23.25^{*}$ & $9^{*}$ & $28.6^{*}$ \\
Median & 25 & 9 & 25 \\
Sd & 8.01 & 3.47 & 8.05 \\
Min-Max & $12-31$ & $6-12$ & $19-37$ \\
\hline
\end{tabular}

$\mathrm{F}_{2}=9.068, \mathrm{p}=0.006(\mathrm{p}<0.05)$

Post Hoc Bonferroni * p=0.049 $(\mathrm{p}<0.05), \mathrm{p}=0.006(\mathrm{p}<0.05)$

Note : $\mathrm{F}_{2}=$ ANNOVA test; $\mathrm{Sd}=$ Standard deviation

Table 10 above showed the thickness of fibroblasts in wound healing after treatment day 7 found a significant difference between curcumin $0.5 \%$ with $\mathrm{NaCl} 0.9 \%$. Similarly, curcumin $5 \%$ with $\mathrm{NaCl} 0.9 \%$ which the biggest fibroblasts thickness at $\mathrm{NaCl} 0.9 \%$ group.

\section{Discussion}

The results from wound diameter analysis in wound healing, showed a significant difference between the mean diameter macroscopic lesion before and after treatment in all three groups after 3 days ( $p<0.05)$, although visible under macroscopic wound diameter are best found in $\mathrm{NaCl} 0.9 \%$ group $(\mathrm{p}=0.005)$. Followed in the curcumin $0.5 \%$ group $(\mathrm{p}=$ $0.016)$ and the last at curcumin $5 \%$ group $(p=0.04)$. Statistical analysis compared which is better than the diameter difference between the three groups wound after 3 days of treatment, showed no significant difference $(p=0.178)$ This is according to research conducted by Purohit et al, that curcumin has the effect of therapy in wound healing. ${ }^{(6)}$

Comparison of the mean diameter macroscopic lesion before and after treatment in all three groups after 7 days, only at $5 \%$ curcumin $(\mathrm{p}=0.004)$ and $\mathrm{NaCl} 0.9 \%(\mathrm{p}=0.000)$ that there are significant differences. A possibility that this could be due to an infection in curcumin $0.5 \%$ group $(\mathrm{P}=0.477)$. If viewed from the mean difference in diameter wound macroscopically there is no significant difference between groups curcumin $5 \%$ and $\mathrm{NaCl} 0.9 \%$.

If we look further, we compare the diameter of the wound after treatment on day 3 between curcumin $5 \%$ (mean $=3,8 \mathrm{~mm})$ $\mathrm{NaCl} 0.9 \%($ mean $=3,6 \mathrm{~mm})$ and at day 7 between curcumin $5 \%$ (mean $=2,8 \mathrm{~mm}) \mathrm{NaCl} 0.9 \%$ (mean $=2.5 \mathrm{~mm}$ ) is appropriate that the results of curcumin administration in wound healing can heal wounds, but not better than $\mathrm{NaCl} 0.9 \%$.

Analysis of reepithelization in wound healing, based on data from Table 5 and Table 6 reepithelization most value are those of curcumin $5 \%(191 \mu \mathrm{m})$, curcumin $0.5 \%(191.5 \mu \mathrm{m})$ and $0.9 \% \mathrm{NaCl}(236 \mu \mathrm{m})$. But statistically, no significant differences found reepitelisasi length obtained from long injury, after treatment day 3 in all three groups $(\mathrm{p}=0.417)$. Reepithelization after treatment day 7 (Table 6) showed a significant difference between the mean curcumin $0.5 \%$ (178 $\mu \mathrm{m})$ and a mean of $\mathrm{NaCl} 0.9 \%(69 \mu \mathrm{m})(\mathrm{p}=0.027)$, and compared with curcumin $0,5 \%$. In study conducted by Purohit et al which examined the effects of wound healing using of Curcuma longa (Turmeric) rhizomes, are used for wound healed, it possesses antibacterial, anti-inflammatory, anti-allergic properties. ${ }^{(6)}$

If we look further, and we compare statistical data the reepithelization of wound healing after treatment on day 3 and day 7 seems there is a tendency smaller length value lesions (greater length reepithelization Table 7 and 8). It showed after treatment day $7, \mathrm{NaCl} 0.9 \%$ showed better results, in terms of reepithelization.

Analysis of PMN and macrophages density in wound healing, based on data from the three groups of the distribution of the density of PMN and macrophages after treatment on day 3 obtained a significant difference between curcumin $0.5 \%$ (62.6) with $\mathrm{NaCl} 0.9 \%(35.8)(\mathrm{p}=0.028)$ and curcumin $5 \%$ (63.2) with $\mathrm{NaCl} 0.9 \%(p=0.023)$.

In contrast to the three groups of the distribution of the density of PMN and macrophages after treatment day 7 curcumin $0.5 \%$ (52.6) curcumin 5\% (32.4) and $\mathrm{NaCl} 0.9 \%$ (62.8) is not found significant difference, although it appears that the percentage of the density of most higher categories in $\mathrm{NaCl} 0.9 \%$ and the lowest at curcumin 5\%group. Prevention of wound infection can guarantee a normal proliferation of tissue cells to cover the wound. ${ }^{(6)}$ And the same thing happens to the research conducted by Mani, that the density of PMN and macrophages many categories highest in $\mathrm{NaCl} 0.9 \%$ group $(100 \%)$ in acute wound healing in mice. ${ }^{(7)}$.In the group $\mathrm{NaCl} 0.9 \%$ were found to foci of bacterial infection that PMN and macrophages in significant amounts phagocytes bacteria. ${ }^{(7)}$ This may be caused by environmental factors such as the condition of the mice cages or host factors such as the 
behavior of mice after the wound was made. ${ }^{(8)}$ Sodium chloride has the effect of inhibiting the growth of bacteria in high concentrations of over $20 \mathrm{~g} / \mathrm{L}$. However, at low concentrations, $\mathrm{NaCl}$ in the water phase can increase the growth of bacteria. ${ }^{(8,9,10)}$ Sodium chloride $0.9 \%$ containing 9 grams of salt per liter. This causes the growth of bacteria in the group of mice given $\mathrm{NaCl} 0.9 \%$ wet dressings. ${ }^{(8,11,12)}$

If we look further, we compare statistical data density of PMN and macrophages wound healing after treatment on day 3 appears $\mathrm{PMN}$ and macrophage density value in the delivery of $\mathrm{NaCl} 0.9 \%$ slower, but at day $7 \mathrm{PMN}$ and macrophage density values the provision of $\mathrm{NaCl} 0.9 \%$ gave similar results by administering curcumin and curcumin $0.5 \%$ to $5 \%$, and the value of the density of PMN and macrophages to the administration of $\mathrm{NaCl} 0.9$ and a rising trend clearly visible.

Analysis of fibroblasts thickness in wound healing similarly, in table 12 the value of the thickness of fibroblasts curcumin 0.5 $\%($ mean $=34 \mu \mathrm{m})$ curcumin $5 \%($ mean $=28 \mu \mathrm{m}) \mathrm{NaCl} 0.9 \%$ (mean $=19 \mu \mathrm{m})$ showed no significant differences in the thickness of the fibroblasts in the three groups after treatment day $3(p=0.05)$. While the thickness of fibroblasts after treatment day 7 there is a significant difference between curcumin $0.5 \%($ mean $=23.23 \mu \mathrm{m})$ with $\mathrm{NaCl} 0.9 \%$ (mean $=$ $28.6 \mu \mathrm{m})(\mathrm{p}=0.49)$ and curcumin $5 \%($ mean $=9 \mu \mathrm{m})$ with $\mathrm{NaCl}$ $0.9 \%($ mean $=28.6 \mu \mathrm{m})(\mathrm{p}=0.06)$. It is appropriate that the fibroblasts begin to decline at day 7 marks the proliferative phase towards remodeling. ${ }^{(11,12)}$ Wound healing is a complex biological process and dynamic, which consists of 3 phases which inflammation, tissue formation and remodeling. ${ }^{(13)}$ Normal wound healing requires good circulation, nutrition, and immune status. Generally necessary process for 3-14 days for complete recovery. ${ }^{(14)}$ In the process reepithelization, fibroblasts restore network stability by producing collagen, fibronectin, elastin, and peptidoglycan. The formation of the matrix fibers will cause a significant reduction in wound size. ${ }^{(15)}$

If we look further, if we compare statistics the thickness of fibroblasts on wound healing after treatment on day 3 and day 7 seems there is a tendency smaller thickness value fibroblasts $\mathrm{NaCl} 0.9 \%$ lower on day 3 , but on the day to 7 thickness values of fibroblasts in the provision of $\mathrm{NaCl} 0.9 \%$ showed better results.

\section{References}

[1] Chu, D.H. Development and structure of skin. In: Goldsmith L.A., Katz, S. I., Gilchrest, B.A., Paller, A.S., Leffel, D.J., Wolff, K, eds. Fitzpatricks Dermatology in General Medicine.8th ed. 2012. McGraw Hill: New York
[2] Lazarus, G.S., Cooper, D.M., Knighton, D.R., Percoraro, R.E., Rodeheaver, G., Robson, M.C. Definitions and guidelines for assessment of wounds and evaluation of healing. Wound Repair Regen.1994; 2: 165-70

[3] Lee, H., Li, Y., Phillips, T., Woodley, D.T. Wound healing. In Roenigk, R. K., Ratz, J.L., Roenigk, H.H, eds. Roenigk's Dermatologic Surgery.2007; Informa healthcare: New York.

[4] Chin, G.A., Diegelmann, R.F., Schultz, G.S. Cellular and Molecular regulation of wound healing. In Falabella, A. F., Kirsner, R. S (eds). Wound healing.2005; Taylor and Francis: Boca.

[5] Utami, A.N. Perbandingan Efek Anti Inflamasi Kurcumin 1\% dalam Vehikulum Krim dan Salep pada Kulit Mencit yang Telah Disinari Sinar Ultraviolet. Journal Tesis. FKUI: Jakarta.

[6] Purohit, S.K., Solanki, R., Madhur, V., Madhur, M. Evaluation of Wound Healing Activity of Ethanolic Extract of Curcuma Longa Rhizomes in Male Albino Rats. Asian J. Pharm. Res. 2013; 3(2): 79-81.

[7] Mani, H., Sidhu, G.S., Gaddipati, J.P., Seth, P., Maheshwari, R.K. Curcumin Differentially Regulates TGF- $\beta 1$, its Reseptors and Nitric Oxide Synthase During Impaired Wound Healing. BioFactors. 2002; 16: 29-43.

[8] Fagraeus A. 1949. Influence of sodium chloride on growth of staphylococci and some other bacteria. ActaPeth Micro Scand. 26:655-65.

[9] Neysens P, Messens W, Vuyst LD. 2003. Effect of sodium chloride on growth and bacteriocin production by Lactobacillus amylovorusDCE 471. Int J Food Micro 88:29-30.

[10] World Health Organization. 2013. The International Pharmacopoeia.

[11] Young SR, Dyson M, Lang S, Osborn C. 2001. Comparison of the effects of semi-occlusive polyurethane dressings and hydrocolloid dressing on dermal repair: 1. Cellular changes. J Invest Dermatol 97:586-92.

[12] Vogt, P. M., Andree, C., Breuing, K., Liu, P. Y., et al. 1995. Dry, moist, and wet skin wound repair. Ann Plas Surg. 34: 493-500

[13] Eming, S.A., 2012. Biology of Wound Healing. In BologniaJ.L., Jorizzo, J.L.,Schaffer, J.V (eds). Dermatology. Elsevier limited.

[14] Fonder, M. A., Lazarus, G. S., Cowan, D. A., Aronson-Cook, B., Kohli, A. R., Mamelak, A. J. 2008. Treating the chronic wound: A practical approach to the care of nonhealing wounds and wound care dressings.J Am Acad. 58: 185-206

[15] Leong, M., Phillips, LG. 2012. Wound healing. In Townsend, CM., Beauchamp, RD., Evers, M., Mattox, KL (eds). Sabiston Textbook of Surgery. Saunders. 